\title{
Micro-/Nano-Scales Direct Cell Behavior on Biomaterial Surfaces
}

\author{
Shuo Wang, Jingan Li * (D), Zixiao Zhou, Sheng Zhou and Zhenqing Hu \\ School of Material Science and Engineering \& Henan Key Laboratory of Advanced Magnesium Alloy \& Key \\ Laboratory of materials processing and mold technology (Ministry of Education), Zhengzhou University, \\ Zhengzhou 450001, China; snowsunny24@gmail.com (S.W.); ZhouZixiao323@163.com (Z.Z.); \\ zhousheng729@163.com (S.Z.); huzhenqing666@163.com (Z.H.) \\ * Correspondence: lijingan@zzu.edu.cn; Tel.: +86-185-3995-6211
}

Academic Editor: Guillaume Delaittre

Received: 22 October 2018; Accepted: 20 December 2018; Published: 26 December 2018

\begin{abstract}
Cells are the smallest living units of a human body's structure and function, and their behaviors should not be ignored in human physiological and pathological metabolic activities. Each cell has a different scale, and presents distinct responses to specific scales: Vascular endothelial cells may obtain a normal function when regulated by the $25 \mu \mathrm{m}$ strips, but de-function if the scale is removed; stem cells can rapidly proliferate on the $30 \mathrm{~nm}$ scales nanotubes surface, but stop proliferating when the scale is changed to $100 \mathrm{~nm}$. Therefore, micro and nano scales play a crucial role in directing cell behaviors on biomaterials surface. In recent years, a series of biomaterials surface with micro and/or nano scales, such as micro-patterns, nanotubes and nanoparticles, have been developed to control the target cell behavior, and further enhance the surface biocompatibility. This contribution will introduce the related research, and review the advances in the micro/nano scales for biomaterials surface functionalization.
\end{abstract}

Keywords: biomaterials surface; surface functionalization; micro/nano scales; cell behavior

\section{Introduction}

One of the key strategies of tissue engineering is to understand how cells respond to external guidance signals from the surrounding microenvironment. In addition to biological and chemical signals (such as growth factors, hormones, and small chemicals), physical cues including topography and hardness are also considered to be important factors that influence cell behaviors [1-3]. Cells exist in complex microenvironments with extracellular matrix (ECM) as the main component. The ECM of various natural tissues such as bone [4], cartilage [5], nerves [6] or blood vessels [7] are composed of micro scale and nano scale topographic patterns. Recent studies have shown that topographical factors such as size, shape, and geometric alignment have strong influence on the adhesion, migration, arrangement, and differentiation of many cells [8-15]. The size of the terrain seems to play a crucial role in regulating cell behavior. Although the responses of the cells to the topography are diverse and closely related to cell type, all types of cells appear to be affected by size (e.g., width, spacing, and feature depth).

The primary concern of this review is to emphasize the importance of different topographical scales, and their impact on related cellular behavior, including micro-patterns, nanotubes and nanoparticles (Figure 1). In order to develop materials and surfaces suitable for tissue engineering applications, it is important to understand how cells respond to topography at different length scales. 


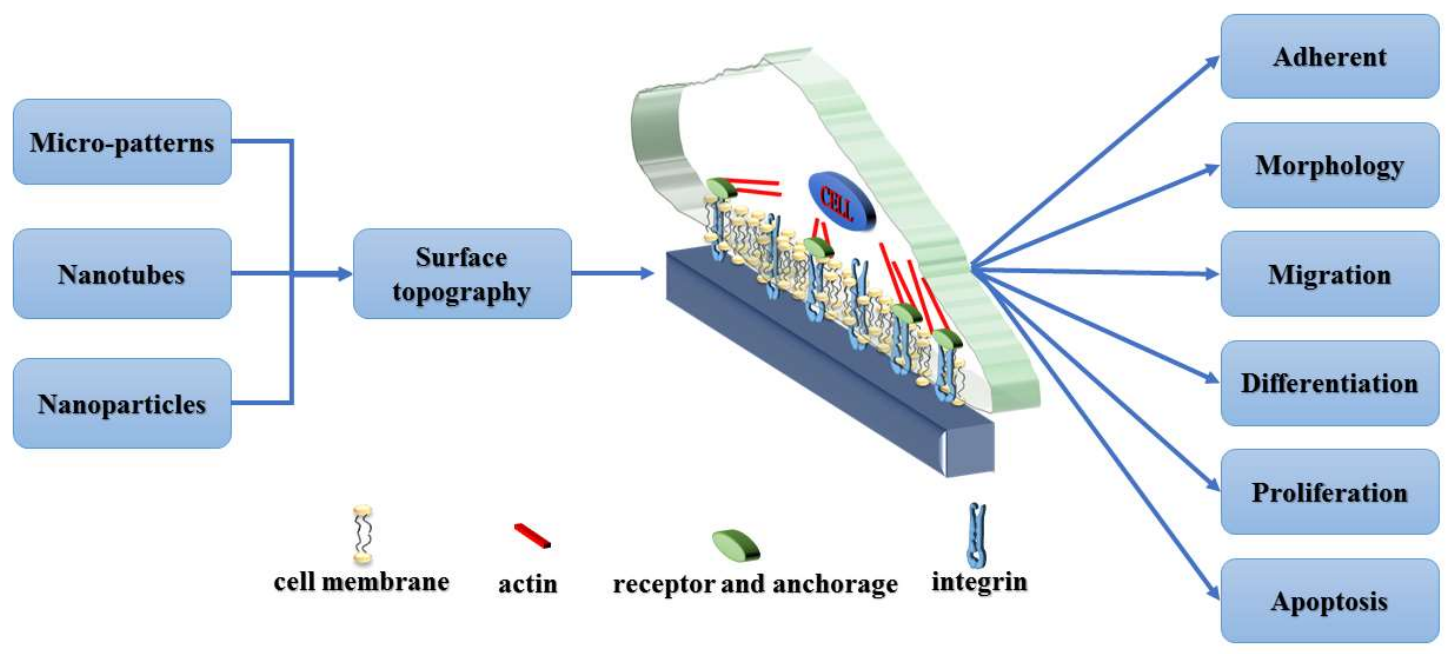

Figure 1. The schematic diagram of the effect of topographic scale on cell behavior.

\section{Application of Micro-Patterns in Biomaterials}

Cell micro-patterns have a wide range of applications in tissue engineering. The activity of cells is highly dependent on their microenvironment, such as the scaffold and surrounding cells. Therefore, designing the cellular microenvironment is of great significance. There are several methods that allow the creation of micro scaled bio-patterns on materials, and most studies use lithography such as micro-contact printing (MCP) [16], microfluidic patterning [17], micromolding [18] or ultraviolet (UV) lithography [19]. Hirschbiel et al. used UV photolithography to form micro-patterns on polycarbonate (PC) films to regulate cell behavior [20]: Co-culture of PAC2 fibroblasts cells showed that irradiation was beneficial to cell adhesion and growth. In order to control the adhesion of MC3T3 cells, Chollet et al. used UV excimer laser ablation and photolithography to covalently graft arginine-glycine-aspartic acid (RGD)-containing peptides onto the polyethylene terephthalate (PET) surface to form micro-patterns [21]. The results showed that the RGD peptide enhanced the adhesion of the cells to PET, and the spreading of the cells appeared to be related to the width of the RGD layer, with the best effect at 25-125 $\mu \mathrm{m}$. Regardless of the space between the RGD domains, cells appeared to be aligned and connected on the RGD region. In addition, the size of the pattern (the width of the RGD layer) also seemed to be a very important parameter, and the MC3T3 cell spread better when the RGD thickness was about $100 \mu \mathrm{m}$. To regulate the distribution, morphological, and cytokine secretion of human vascular endothelial cells (EC), Li et al. fabricated hyaluronic acid (HA) micro-strips with different sizes on the cardiovascular materials surface to simulate the blood flow effect on EC in vitro. Their series of biological evaluation indicated that the HA micro-strips of $25 \mu \mathrm{m}$ obtained a similar effect as with blood flow on regulating endothelial cells (Figure 2) [22]. The differences in the distribution and morphology of EC on each differently-sized micro-strip indicate that the size of the micro-strip is closely related to its effect on EC regulation. Although the HA micro-strip on the materials surfaces can elongate the morphology of EC, thereby enhancing the deposition of endothelial ECM, the HA micro-strip showed poor blood compatibility [22]. In order to solve this problem, $\mathrm{Li}$ et al. then proposed a method for combining HA micro-strips with EC decellularization as shown in Figure 3 [23]. Their further biological evaluation consistently demonstrated HA-patterned endothelial ECM had series of functions to improve the surface biocompatibility [24]. Nevertheless, the above modification techniques may be limited to the continuous flat surface of large devices, because the micro scale on the small devices with good elasticity (such as stents) may change when the devices are opened. 

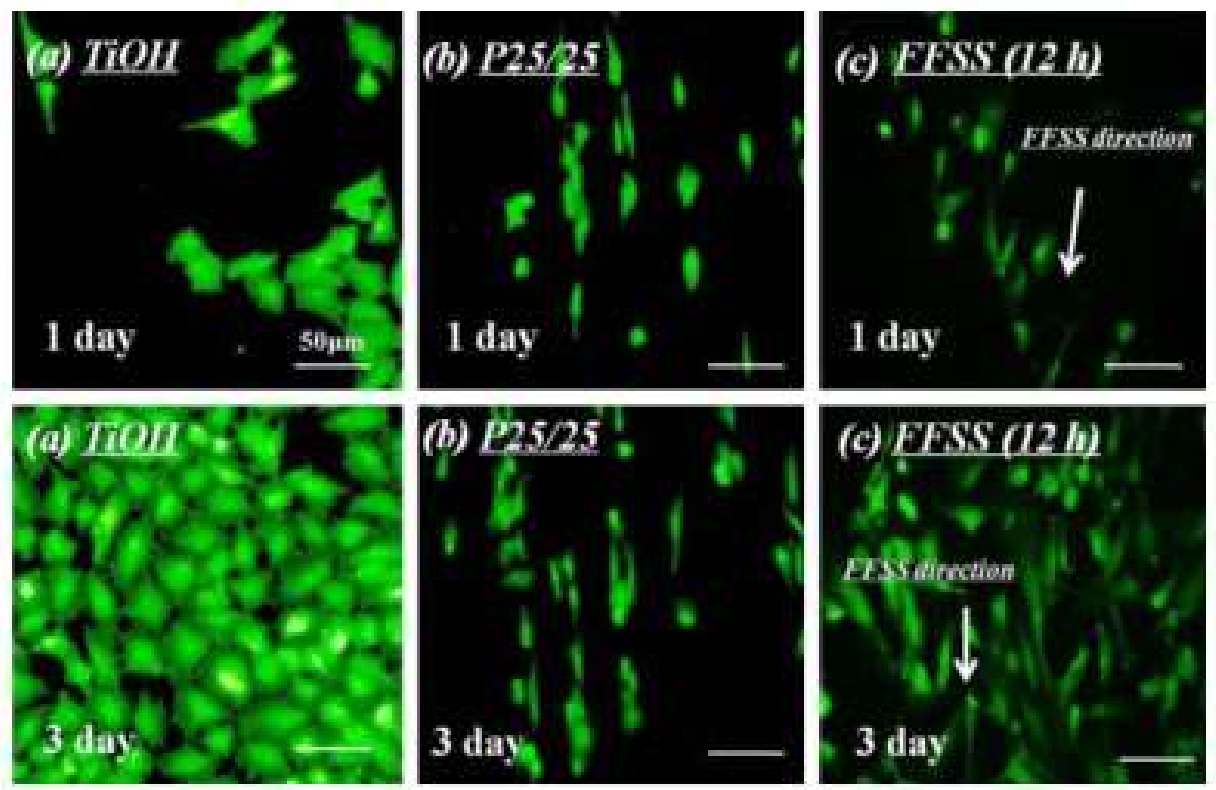

Figure 2. In the cited images, Li et al. prepared hyaluronic acid micro-strips with $25 \mu \mathrm{m}$ size (samples were labeled as (b) P25/25) on the $\mathrm{NaOH}$ treated titanium surface to control the vascular endothelial cells' morphology. The study demonstrated that the vascular endothelial cells controlled by P25/25 presented a similar morphology (elongation) with the vascular endothelial cells under $15 \mathrm{dyn} / \mathrm{cm}^{2}$ fluid flow shear stress (samples were labeled as (c) FFSS, it is also the average blood flow shear stress in the human blood vessels). The vascular endothelial cells on the single $\mathrm{NaOH}$ treated titanium control (samples were labeled as (a) $\mathrm{TiOH}$, and it was flat) showed round and polygonal morphologies which were different from the cells on P25/25 or under FFSS [22]. Copyright 2013, Elsevier.

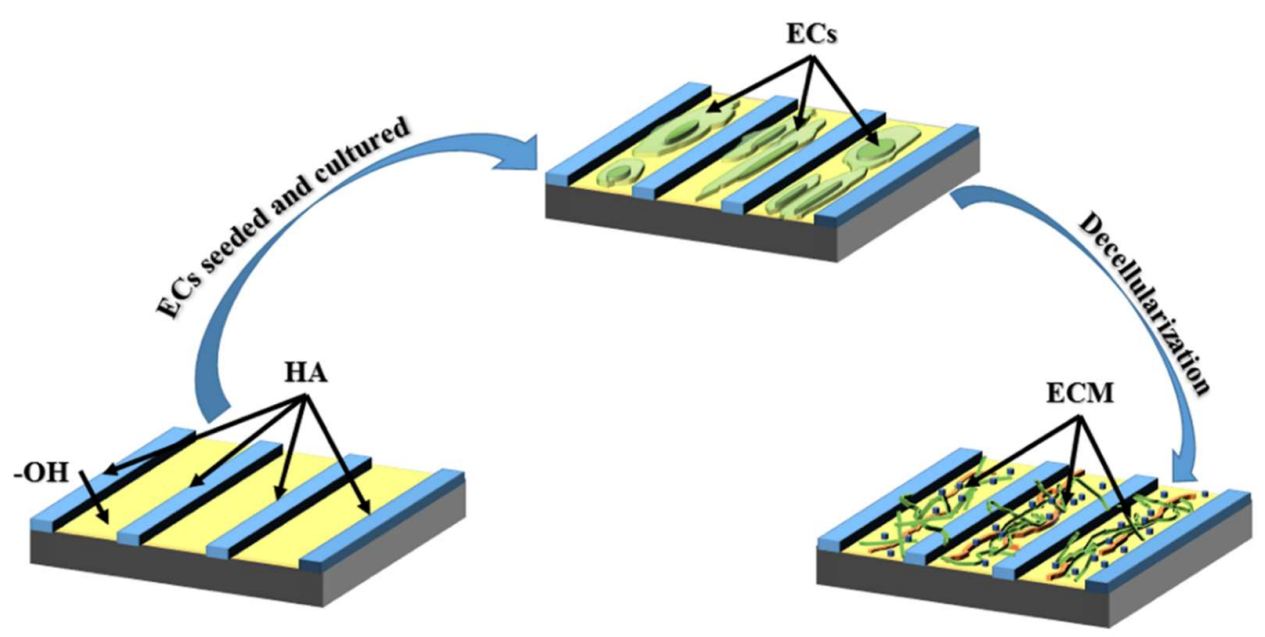

Figure 3. The scheme of preparing hyaluronic acid (HA)-patterned extracellular matrix (ECM): To obtain better biocompatibility, Li et al. controlled the vascular endothelial cells (EC) via preparing hyaluronic acid micro-pattern on materials surfaces to simulate the in vivo blood flow condition, and the extracellular matrix secreted by the patterned EC also showed similar property with the EC in vivo; Further investigation proved that the ECM left on the HA micro-pattern after decellularization had better biocompatibility compared to the ECM secreted by those EC on non-patterned surface [23].

Laser micro-patterning has been developed rapidly because of its rapid and precise processing [25]. Liang et al. prepared vascular smooth muscle cell (VSMC) micro/nano biomimetic surface patterns on 316L stainless steel (316L SS) by using femtosecond laser (FSL), processing to achieve the purpose of rapid endothelialization [26]. Cell and animal experiments show that it can promote the adhesion 
and proliferation of human umbilical vein endothelial cells (HUVECs) and inhibit the proliferation of VSMC as to achieve rapid endothelialization. In recent years, the appearance of direct laser writing (DLW) has made it possible to form micro/nano scale three-dimensional (3D) micro-patterns on the surface of materials $[27,28]$. Klein et al. prepared polymer scaffolds with 3D microstructures from two different photoresist by continuous DLW method, and achieved the purpose of regulating cell adhesion from 3D scale for the first time [29]. Richter et al. used DLW for the first time to control the chemical properties of the surface of 3D micro-scaffolds [30]. Claus et al. used two new photoresists with photo-reactive groups to realize the multiplex and simultaneous orthogonal functionalization of 3D microstructures by DLW technology for the first time, which has a good prospect of application [31]. On the basis of their original work, Richter et al. prepared a DLW 3D micro-scaffold by combining a protein repellent photoresist with a protein adhesive and a photo-activated passivated adhesive. The co-culture of epithelial cells (A549) showed that the bioactive functionalization of two different ECM proteins on the 3D micro-scaffold was realized for the first time [32].

Electro-spinning is also a common method in tissue engineering [33]. Both grooved micro-patterns and electro-spun fibers can affect the adhesion and proliferation of EC [34]. Electro-spinning techniques are commonly used to fabricate tissue-engineered fiber scaffolds [35]. Yoshimoto et al. made poly (e-caprolactone) (PCL) into nanofiber scaffolds by electro-spinning. Cell experiments showed that the scaffolds had potential for bone repair [36]. Min et al. also used silk fibroin (SF) to make wound dressings by electro-spinning [37]. Li et al. combined bone morphogenetic protein-2 (BMP-2) and nanoparticulate hydroxyapatite with electrostatic spinning scaffold for bone tissue engineering [38]. Frohbergh et al. enhanced the biocompatibility of the electro-spinning scaffolds by crosslinking with genipin [39]. Moffa et al. used electro-spinning and soft lithography to fabricate nanofiber scaffolds with different micro-patterns [40]. Through observation of various behaviors of EC, it is found that micro-patterns play a beneficial role in the regulation of EC and promote the regeneration of EC with complete functions. Rogers et al. combined the additive manufacturing (AM) method with electro-spinning to prepare fiber scaffolds with surface micro-patterns [41]. Observing the adhesion and proliferation of 3T3 fibroblasts, the cells first adhered to the micro-patterned regions and exhibited an undulating structure after proliferation in the sinusoidal region, indicating that the patterning of the electro-spun scaffold can affect the behavior of the cells.

In addition to EC and 3T3 cells, mesenchymal stem cells (MSCs) that are present around the blood vessels also play an important role in tissue engineering and bone repair [42]. Phipps et al. used polyethylene oxide (PEO) sacrificial fiber to enhance cell infiltration in PCL, collagen I and hydroxyapatite electro-spun scaffolds, and MSC adhesion [43]. To study the behavior of human bone marrow mesenchymal stem cells (HMSCs), Ynsa et al. used a high-energy proton beam to prepare a geometric micro-patterned surface in which silicon and porous silicon (Si/PSI) were combined [44]. The Si/PSI patterns promoted cell adhesion and migration and maintained the expression of major bone transcription factors, as well as intercellular interactions with good results. The surface morphology, charge density, surface energy and wettability of biological materials all affected the proliferation and differentiation of stem cells [45-47]. Tan et al. designed a micro-patterned polymer brush platform that could exclude the effects of other surface properties and study the effects of microenvironment on epidermal stem cell differentiation [48]. It was found that moderate hydrophobicity did not affect the differentiation and adhesion of stem cells, while strong negative surface potential increased the differentiation rate. This platform could simultaneously detect multiple cell microenvironment parameters, which had a certain impetus to the development of biomaterials.

Surface micro-patterning of biomaterials is an important mean of regulating cell behavior $[49,50]$. Changes in topographic and surface mechanical properties lead to changes in cell morphology and function [51-53]. Bulk metallic glass (BMGs) are especially suitable for micro/nano scale processing due to their unique superior properties [54-58]. Because of its excellent stability, BMGs is capable of forming thermoplastic forming (TPF) in a subcooled liquid region that is significantly below the melting temperature [59]. Wang et al. found a method for preparing graded micro/nano patterns of 
platinum-BMG (Pt-BMG) on the corresponding length scale [60]. The morphology of macrophages and fibroblasts was analyzed by in vitro cell culture experiments, and these two cell types were critical for the response to foreign bodies. The results showed that the morphological changes of macrophages and fibroblasts were significantly different, and the activation states were less. Different length scales could systematically influence the corresponding cell type-specific responses, and biomaterials with nano-topographic features could perform better and longer.

\section{Application of Nanotubes in Biomaterials}

In recent years, highly ordered, vertically-oriented titanium dioxide nanotube $\left(\mathrm{TiO}_{2} \mathrm{NT}\right)$ arrays prepared by electrochemical anodization of titanium (Ti) and its alloys have attracted wide interest as biomedical coatings [61,62]. The diameter and length can be precisely determined by changing the anode parameters. Due to their self-organizing nature, even complexly shaped surfaces can be coated relatively easily [61]. $\mathrm{TiO}_{2} \mathrm{NT}$ arrays have excellent biological properties in vivo and in vitro studies. For example, the $\mathrm{TiO}_{2} \mathrm{NT}$ array has a good effect on the functions of various cells such as EC $[63,64]$, vascular smooth muscle cells [63], human mesenchymal stem cells [65,66], and osteoblasts [67,68]. In order to improve the antibacterial properties, Gao et al. deposited $\mathrm{Ti}-\mathrm{Ag}$ coating on $\mathrm{Ti}$ and then anodized to prepare silver oxide $\left(\mathrm{Ag}_{2} \mathrm{O}\right)$ nanoparticle embedded $\mathrm{TiO}_{2} \mathrm{NT}$ array $\left(\mathrm{NT}-\mathrm{Ag}_{2} \mathrm{O}\right.$ array) [69]. Long-term culture results of Staphylococcus aureus and Escherichia coli showed that NT- $\mathrm{Ag}_{2} \mathrm{O}$ arrays have long-term effective antibacterial ability and can effectively kill adhering bacteria. The culture of MC3T3-E1 cells showed that $\mathrm{NT}-\mathrm{Ag}_{2} \mathrm{O}$ arrays have good cytocompatibility and can promote the spreading, proliferation, and differentiation of osteoblasts. Wang et al. used a hybrid system of metal ion coordination polymers on the surface of titanium dioxide nanotubes (TNTs) to improve antibacterial properties [70]. They loaded antibacterial agents such as antibiotics and nano-silver particles into TNTs, and then sealed them with metal ions such as $\mathrm{Zn}^{2+}$ or $\mathrm{Ag}^{+}$attachment coordination polymers $(\mathrm{CPs})$. When $\mathrm{pH}$ is maintained at 7.4, the strong bonding of $\mathrm{CPs}$ can maintain the amount of released antimicrobial agents at a non-significant level. However, the acidic environment will trigger the coordination bond of the modified CP to open from the TNTs and release the antimicrobial agent. The proliferation of osteoblastic cells can be promoted by $\mathrm{Zn}^{2+}$, while the antibacterial capability can be enhanced by $\mathrm{Ag}^{+}$. Except zinc and silver, strontium (Sr) also has a dual role in improving bone formation and inhibiting bone resorption [71,72]. In order to incorporate $\mathrm{Sr}$ into $\mathrm{TiO}_{2} \mathrm{NTs}$, Chen et al. embedded $\mathrm{TiO}_{2}$ NTs containing $\mathrm{Ag}_{2} \mathrm{O}$ NPs (NT-Ag) into $\mathrm{Ag}_{2} \mathrm{O}$ nanoparticles (expressed as NT-Sr-Ag) by hydrothermal treatment in the $\mathrm{Sr}(\mathrm{OH})_{2}$ solution [73]. The morphology of the NTs was not altered by the hydrothermal treatment, but the amorphous $\mathrm{TiO}_{2}$ in $\mathrm{NT}-\mathrm{Ag}$ converted into cubic $\mathrm{SrTiO}_{3} . \mathrm{Sr}^{2+}$ and $\mathrm{Ag}^{+}$can be constantly released from NT-Sr-Ag, which possesses long-lasting antibacterial activity, good osteogenic, angiogenic activities and has clinical potential. Manganese $(\mathrm{Mn})$ is also an element that is beneficial to bone regeneration [74]. Huang et al. used anodization and electrodeposition techniques to modify titanium implants with a two-layer coating co-doped with TNTs and hydroxyapatite with silver and manganese (AgMnHA) [75]. The addition of silver to hydroxyapatite improved its antibacterial properties, and the doping of manganese counteracted the potential cytotoxicity of the incorporated silver. The coating produced an excellent antibacterial effect by continuous release of silver ions. In vitro cell culture assays showed that osteoblast viability and alkaline phosphatase (ALP) activity were significantly improved. Therefore, the AgMnHA coating showed no significant cytotoxicity to osteoblasts and was able to produce sufficient osteoblast differentiation for osseointegration.

Bone tissue is a natural structure that includes both micro scale and nano scale [76]. For the sake of simulating the layered structure of bone tissue, Zhao et al. prepared biomimetic hierarchical micro/nano-textured surface topographies on Ti by acid etching and formed nano-tubular structures by anodization [77]. The micromorphology of acid etching induced higher initial cell adhesion and expression of osteogenic related genes, but other cellular behaviors such as proliferation, total intracellular protein synthesis and ALP activity, ECM deposition, and mineralization 
obviously decreased. After the addition of nanotubes to the surface of the micro-well, although cell adhesion and gene expression were slightly decreased, functions of cell proliferation, total intracellular protein synthesis and ALP activity, ECM deposition, and mineralization were able to be maintained or enhanced. Thus, better osseointegration in vivo may be resulted by this hierarchical micro/nano-textured surface topography.

Dopamine can be adhered to most materials and has good biocompatibility [78]. Jia et al. and Hong et al. used polydopamine (PDA) to load silver nanoparticles on titanium dioxide nanotubes $\left(\mathrm{TiO}_{2} \mathrm{NTs}\right)$ to kill bacteria $[79,80]$. However, the polymerization of dopamine and the reaction of PDA with silver nitrate require longer reaction times. Furthermore, difficulty in controlling the deposition of silver nanoparticles may increase the risk of cytotoxicity $[79,81,82]$. To overcome these shortcomings, Ding et al. prepared the PDA film in a $90{ }^{\circ} \mathrm{C}$ water bath $(\mathrm{PDA}-\mathrm{H})$ by performing a rapid reaction on the $\mathrm{TiO}_{2} \mathrm{NTs}$ [83]. In addition, the polydopamine-zinc (PDA-Zn) film formed on the surface of $\mathrm{TiO}_{2}$ NTs by dopamine and zinc nitrate solution significantly accelerated the reduction of $\mathrm{Ag}^{+}$ions under the same heating conditions. The reaction time of the PDA-Zn film with silver nitrate was significantly shortened, and the silver nanoparticles deposited on the PDA- $\mathrm{Zn}$ film were more uniform than the silver nanoparticles on the PDA-H film. The test results showed that the PDA- $\mathrm{Zn}-\mathrm{Ag}-\mathrm{TiO}_{2} \mathrm{NTs}$ material exhibited good antibacterial activity, lower cytotoxicity, and better biocompatibility.

More than $\mathrm{TiO}_{2}$ nanotubes, carbon nanotubes are also a commonly used material in tissue engineering [84]. Lately, natural polymers have provided more benefits than synthetic polymeric materials and have gained widespread interest in biomedical materials. Among these, bacterial cellulose $(\mathrm{BC})$ has gained particular interest more recently $[85,86]$. $\mathrm{BC}$ is a polysaccharide used in the manufacture of reinforced paper, and has been studied as a medical material in recent years [87-89]. Gutierrez-Hernandez et al. combined natural BC with functionalized multi-walled carbon nanotubes (MWNTs) as raw biomaterials for 3D scaffolds for osteoblast culture [90], and functionalized MWNTs with native BC (secreted by Gluconacetobacter xylinus) to enhance the mechanical properties of BC. The results showed that the BC-MWNTs scaffold had a higher level of osteoblast activity, adhesion, and proliferation than the conventional culture substrates. These results indicate that the combination of $\mathrm{BC}$ and carbon nanomaterials has potential as a scaffold for bone regeneration.

\section{Application of Nanoparticles in Biomaterials}

Certain research demonstrated that the main cause of implant failure is the risk of biofilm-associated infection [91-93]. Scientists are designing new strategies to combat implant infections, focusing on the development of new biomaterials with anti-infective properties, and modifying the surface of biomaterials [94-96]. Recently, the application of silver nanoparticles (AgNPs) as antibacterial agents has aroused great interest [97-101]. However, nano-silver enters the cell and stays therein, resulting in local high concentration of silver ion distribution, causing clear toxicity and damage to cells, tissues and organs [102]. Therefore, maintaining the good antibacterial properties of nano-silver and reducing cytotoxicity is key to its application.

Because immobilizing AgNPs to limit their migration is critical to clinical success [102-104], Qin et al. prepared AgNPs in situ by silver plasma immersion ion implantation (PIII) and immobilized them on Ti surfaces [105]. The anti-biofilm activity of immobilized AgNPs was evaluated using the biofilm-producing strain Staphylococcus ermidis. Immobilized AgNPs reduced bacterial biofilm formation by inhibiting bacterial adhesion and icaA/icaD transcription. There was no obvious cytotoxicity in vitro. Anti-biofilm activity was independent of silver release of immobilized AgNPs, and they could protect multiple cycles of bacterial exposure in vitro and reduce implant-related prevention of periprosthetic infection (PPI) in vivo. The effectiveness depended on the Ag-PIII parameters, such as time. By changing the Ag-PIII parameter, the activity of the Ti anti-biofilm could be imparted, which indicates that the clinical use can be prolonged and safely used by reducing PPI. Taglietti et al. used the "layer-by-layer" (LBL) approach to modify the surface of the glass; after the aminosilylation of the glass and immersion in the AgNPs colloidal suspension, the self-assembled 
monolayer (SAM) of AgNPs immobilized on the glass surface was obtained [106]. The results showed that the new AgNPS modified glass had antibacterial/anti-biofilm ability, and not only exhibited good biological properties in terms of anti-infective properties, but also had valuable structural and physicochemical characteristics. More importantly, this surface modification method could be applied not only to glass, but also to most biological materials. Therefore, AgNPs were fixed on the surface to impart excellent antibacterial properties to the material.

Although Ti implants have good biocompatibility, the main challenge is still bacterial infection, with Staphylococcus aureus the main cause of orthopedic implant infection [107]. These bacteria form biofilms that are resistant to host defense mechanisms or antibiotics $[108,109]$. To solve this problem, Jin et al. used metal antibacterial agents such as silver and zinc to make the metal surface resistant to bacteria [110]. Recently, Mohandas et al. used a one-step hydrothermal method to prepare nano-titanium dioxide embedded in silver nanoparticles under alkaline $\mathrm{pH}$ conditions of silver salts [111]. Nano-silver-modified Ti surface not only had strong antibacterial properties, but also promoted the activity, proliferation, and osteogenic differentiation of MSCs. The incorporation of nano-silver into surface-modified Ti by a simple one-step hydrothermal method is a good method for preparing an implant having both antibacterial activity and cytocompatibility.

In the past few decades, Ti has been often used as a medical metal implant in orthopedics. However, as a bio-inert metal implant, it cannot induce bone regeneration after implantation. Bone morphogenetic protein-2 (BMP-2) is one of the important growth factors that induce bone marrow mesenchymal stem cell migration and osteoblast differentiation [112-114], while AgNPs have long-term effective antibacterial properties. In general, silver nanoparticles are prone to agglomeration, resulting in a large increase in local Ag concentration, which may affect cell activity. On the other hand, in order to maintain the activity of the growth factor, its fixation requires mild processing conditions. Therefore, Xie et al. used a combination of electrochemical deposition (ED) and electrostatic immobilization to prepare bone BMP-2 and hydroxyapatite-coated silver nanoparticles on the titanium surface, and selected chitosan (CS) as a stabilizer to achieve a uniform distribution of silver nanoparticles in the hydroxyapatite-coating [115]. While maintaining antibacterial activity, CS also reduced the toxicity of Ag. In addition, CS promoted the immobilization of BMP by electrostatic interactions between biomolecules, including CS, heparin, and BMP. In vitro and in vivo studies have shown that these coatings have high osteoinductivity and antibacterial properties. This method can also be used for surface modification of various metallic implants.

\section{Conclusions}

Specific scales are important parameters for determining the behavior of cells on the surface of biological materials. Cell adhesion, morphology, alignment, and contact guidance are strongly influenced by topographical features of series of micro/nano structures on the materials surfaces, and not only limited to micro-patterns, nanotubes and nanoparticles. In particular, there may be a specific range of scales that will most significantly improve these cellular behaviors. This optimal scale varies with cell type, substrate material and topography. In certain conditions, it seems that the reasonable combination of nano scale and micro scale topography may create better cell microenvironment. Therefore, information about the importance of terrain scales will help design appropriate materials and platforms in tissue engineering.

Author Contributions: Conceptualization, S.W. and J.L.; Methodology, J.L.; Software, S.W.; Validation, S.W., J.L. and S.Z.; Formal Analysis, J.L.; Investigation, S.W.; Resources, J.L.; Data Curation, S.W.; Writing-Original Draft Preparation, S.W.; Writing-Review \& Editing, J.L.; Visualization, S.W.; Supervision, Z.Z.; Project Administration, Z.H.; Funding Acquisition, J.L.

Funding: This research was funded by the National Key Research and Development Program of China grant number [2017YFGX090043-04 and 2016YFC1102403], and the Key Project and Special Foundation of Research, Development and Promotion in Henan province grant number [182102310076].

Conflicts of Interest: The authors declare no conflict of interest. 


\section{References}

1. Nikkhah, M.; Edalat, F.; Manoucheri, S.; Khademhosseini, A. Engineering microscale topographies to control the cell-substrate interface. Biomaterials 2012, 33, 5230. [CrossRef] [PubMed]

2. Kim, H.N.; Jiao, A.; Hwang, N.S.; Kim, M.S.; Kang, D.H.; Kim, D.H.; Suh, K.Y. Nanotopography-guided tissue engineering and regenerative medicine. Adv. Drug Deliver. Rev. 2013, 65, 536-558. [CrossRef] [PubMed]

3. Dalby, M.J.; Gadegaard, N.; Oreffo, R.O.C. Harnessing nanotopography and integrin-matrix interactions to influence stem cell fate. Nat. Mater. 2014, 13, 558. [CrossRef] [PubMed]

4. Mehlhorn, A.T.; Niemeyer, P.; Kaiser, S.; Finkenzeller, G.; Stark, G.B.; Südkamp, N.P.; Schmal, H. Differential expression pattern of extracellular matrix molecules during chondrogenesis of mesenchymal stem cells from bone marrow and adipose tissue. Tissue Eng. 2006, 12, 2853. [CrossRef] [PubMed]

5. Kisiday, J.; Jin, M.; Kurz, B.; Hung, H.; Semino, C.; Zhang, S.; Grodzinsky, A. Self-assembling peptide hydrogel fosters chondrocyte extracellular matrix production and cell division: Implications for cartilage tissue repair. Proc. Natl. Acad. Sci. USA 2002, 99, 9996-10001. [CrossRef] [PubMed]

6. Borkenhagen, M.; Clémence, J.F.; Sigrist, H.; Aebischer, P. Three-dimensional extracellular matrix engineering in the nervous system. J. Biomed. Mater. Res. 1998, 40, 392-400. [CrossRef]

7. Damsky, C.H.; Fitzgerald, M.; Fisher, S. Distribution patterns of extracellular matrix components and adhesion receptors are intricately modulated during first trimester cytotrophoblast differentiation along the invasive pathway, in vivo. J. Clin. Investig. 1992, 89, 210-222. [CrossRef]

8. Abagnale, G.; Steger, M.; Nguyen, V.H.; Hersch, N.; Sechi, A.; Joussen, S.; Denecke, B.; Merkel, R.; Hoffmann, B.; Dreser, A. Surface topography enhances differentiation of mesenchymal stem cells towards osteogenic and adipogenic lineages. Biomaterials 2015, 61, 316-326. [CrossRef]

9. Pek, Y.S.; Wan, A.C.; Ying, J.Y. The effect of matrix stiffness on mesenchymal stem cell differentiation in a 3D thixotropic gel. Biomaterials 2010, 31, 385-391. [CrossRef]

10. Lee, J.; Abdeen, A.A.; Zhang, D.; Kilian, K.A. Directing stem cell fate on hydrogel substrates by controlling cell geometry, matrix mechanics and adhesion ligand composition. Biomaterials 2013, 34, 8140. [CrossRef]

11. Tawfick, S.; De Volder, M.; Copic, D.; Park, S.J.; Oliver, C.R.; Polsen, E.S.; Roberts, M.J.; Hart, A.J. Engineering of Micro- and Nanostructured Surfaces with Anisotropic Geometries and Properties. Adv. Mater. 2012, 24, 1628-1674. [CrossRef] [PubMed]

12. Song, X.; Chang, L.; Wang, J.; Zhu, S.; Wang, L.; Feng, K.; Luo, Y.; Guan, S. Investigation on the in vitro cytocompatibility of Mg-Zn-Y-Nd-Zr alloys as degradable orthopaedic implant materials. J. Mater. Sci. Mater. Med. 2018, 29, 44. [CrossRef] [PubMed]

13. Ma, X.; Zhu, S.; Wang, L.; Ji, C.; Ren, C.; Guan, S. Synthesis and properties of a bio-composite coating formed on magnesium alloy by one-step method of micro-arc oxidation. J. Alloys Compd. 2014, 590, $247-253$. [CrossRef]

14. Wang, H.; Guan, S.; Wang, Y.; Liu, H.; Wang, H.; Wang, L.; Ren, C.; Zhu, S.; Chen, K. In vivo degradation behavior of Ca-deficient hydroxyapatite coated $\mathrm{Mg}-\mathrm{Zn}-\mathrm{Ca}$ alloy for bone implant application. Colloids Surf. B 2011, 88, 254-259. [CrossRef] [PubMed]

15. Wang, J.; Zhou, Y.; Yang, Z.; Zhu, S.; Wang, L.; Guan, S. Processing and properties of magnesium alloy micro-tubes for biodegradable vascular stents. Mater. Sci. Eng. C 2018, 90, 504-513. [CrossRef]

16. Wilbur, J.L.; Kumar, A.; Kim, E.; Whitesides, G.M. Microfabrication by microcontact printing of self-assembled monolayers. Adv. Mater. 1994, 6, 600-604. [CrossRef]

17. Khademhosseini, A.; Eng, G.; Yeh, J.; Kucharczyk, P.A.; Langer, R.; Vunjaknovakovic, G.; Radisic, M. Microfluidic patterning for fabrication of contractile cardiac organoids. Biomed. Microdevices 2007, 9, 149. [CrossRef]

18. Kim, E.; Younan Xia, A.; Whitesides, G.M. Micromolding in Capillaries: Applications in Materials Science. J. Am. Chem. Soc. 1996, 118, 5722-5731. [CrossRef]

19. He, W.; Halberstadt, C.R.; Gonsalves, K.E. Lithography application of a novel photoresist for patterning of cells. Biomaterials 2004, 25, 2055-2063. [CrossRef]

20. Hirschbiel, A.F.; Geyer, S.; Yameen, B.; Welle, A.; Nikolov, P.; Giselbrecht, S.; Scholpp, S.; Delaittre, G.; Barner-Kowollik, C. Photolithographic patterning of 3D-formed polycarbonate films for targeted cell guiding. Adv. Mater. 2015, 27, 2621-2626. [CrossRef] 
21. Chollet, C.; Lazare, S.; Guillemot, F.; Durrieu, M.C. Impact of RGD micro-patterns on cell adhesion. Colloids Surf. B 2010, 75, 107-114. [CrossRef] [PubMed]

22. Li, J.; Zhang, K.; Yang, P.; Qin, W.; Li, G.; Zhao, A.; Huang, N. Human vascular endothelial cell morphology and functional cytokine secretion influenced by different size of HA micro-pattern on titanium substrate. Colloids Surf. B 2013, 110, 199-207. [CrossRef]

23. Li, J.; Zhang, K.; Wu, J.; Zhang, L.; Yang, P.; Tu, Q.; Huang, N. Tailoring of the titanium surface by preparing cardiovascular endothelial extracellular matrix layer on the hyaluronic acid micro-pattern for improving biocompatibility. Colloids Surf. B 2015, 128, 201-210. [CrossRef] [PubMed]

24. Zou, D.; Luo, X.; Li, J.; Wang, S.; Zhang, K.; Sun, J.; Yang, P.; Zheng, Q.; Zhang, C. Investigating Blood Compatibility and Tissue Compatibility of a Biomimetic Extracellular Matrix Layer on Cardiovascular Biomaterials. J. Biomater. Tissue Eng. 2018, 8, 640-646. [CrossRef]

25. Lu, Y.; Chen, S.C. Micro and nano-fabrication of biodegradable polymers for drug delivery. Adv. Drug Deliver. Rev. 2004, 56, 1621-1633. [CrossRef] [PubMed]

26. Liang, C.; Hu, Y.; Wang, H.; Xia, D.; Li, Q.; Zhang, J.; Yang, J.; Li, B.; Li, H.; Han, D.; et al. Biomimetic cardiovascular stents for in vivo re-endothelialization. Biomaterials 2016, 103, 170-182. [CrossRef] [PubMed]

27. Klein, F.; Striebel, T.; Fischer, J.; Jiang, Z.; Franz, C.M.; von Freymann, G.; Wegener, M.; Bastmeyer, M. Elastic fully three-dimensional microstructure scaffolds for cell force measurements. Adv. Mater. 2010, 22, 868-871. [CrossRef] [PubMed]

28. Barner-Kowollik, C.; Bastmeyer, M.; Blasco, E.; Delaittre, G.; Muller, P.; Richter, B.; Wegener, M. 3D Laser Micro- and Nanoprinting: Challenges for Chemistry. Angew. Chem. Int. Ed. 2017, 56, 15828-15845. [CrossRef] [PubMed]

29. Klein, F.; Richter, B.; Striebel, T.; Franz, C.M.; von Freymann, G.; Wegener, M.; Bastmeyer, M. Two-component polymer scaffolds for controlled three-dimensional cell culture. Adv. Mater. 2011, 23, 1341-1345. [CrossRef]

30. Richter, B.; Pauloehrl, T.; Kaschke, J.; Fichtner, D.; Fischer, J.; Greiner, A.M.; Wedlich, D.; Wegener, M.; Delaittre, G.; Barner-Kowollik, C.; et al. Three-dimensional microscaffolds exhibiting spatially resolved surface chemistry. Adv. Mater. 2013, 25, 6117-6122. [CrossRef]

31. Claus, T.K.; Richter, B.; Hahn, V.; Welle, A.; Kayser, S.; Wegener, M.; Bastmeyer, M.; Delaittre, G.; Barner-Kowollik, C. Simultaneous Dual Encoding of Three-Dimensional Structures by Light-Induced Modular Ligation. Angew. Chem. Int. Ed. 2016, 55, 3817-3822. [CrossRef] [PubMed]

32. Richter, B.; Hahn, V.; Bertels, S.; Claus, T.K.; Wegener, M.; Delaittre, G.; Barner-Kowollik, C.; Bastmeyer, M. Guiding Cell Attachment in 3D Microscaffolds Selectively Functionalized with Two Distinct Adhesion Proteins. Adv. Mater. 2017, 29. [CrossRef] [PubMed]

33. Pham, Q.P.; Sharma, U.; Mikos, A.G. Electrospinning of polymeric nanofibers for tissue engineering applications: A. review. Tissue Eng. 2006, 12, 1197-1211. [CrossRef] [PubMed]

34. Feng, Z.Q.; Lu, H.J.; Leach, M.K.; Huang, N.P.; Wang, Y.C.; Liu, C.J.; Gu, Z.Z. The influence of type-I collagen-coated PLLA aligned nanofibers on growth of blood outgrowth endothelial cells. Biomed. Mater. 2010, 5, 065011. [CrossRef] [PubMed]

35. Li, D.; Xia, Y. Electrospinning of Nanofibers: Reinventing the Wheel? Adv. Mater. 2004, 16, 1151-1170. [CrossRef]

36. Yoshimoto, H.; Shin, Y.M.; Terai, H.; Vacanti, J.P. A biodegradable nanofiber scaffold by electrospinning and its potential for bone tissue engineering. Biomaterials 2003, 24, 2077-2082. [CrossRef]

37. Min, B.-M.; Lee, G.; Kim, S.H.; Nam, Y.S.; Lee, T.S.; Park, W.H. Electrospinning of silk fibroin nanofibers and its effect on the adhesion and spreading of normal human keratinocytes and fibroblasts in vitro. Biomaterials 2004, 25, 1289-1297. [CrossRef]

38. Li, C.; Vepari, C.; Jin, H.-J.; Kim, H.J.; Kaplan, D.L. Electrospun silk-BMP-2 scaffolds for bone tissue engineering. Biomaterials 2006, 27, 3115-3124. [CrossRef]

39. Frohbergh, M.E.; Katsman, A.; Botta, G.P.; Lazarovici, P.; Schauer, C.L.; Wegst, U.G.; Lelkes, P.I. Electrospun hydroxyapatite-containing chitosan nanofibers crosslinked with genipin for bone tissue engineering. Biomaterials 2012, 33, 9167-9178. [CrossRef]

40. Moffa, M.; Sciancalepore, A.G.; Passione, L.G.; Pisignano, D. Combined nano- and micro-scale topographic cues for engineered vascular constructs by electrospinning and imprinted micro-patterns. Small 2014, 10, 2439-2450. [CrossRef] 
41. Rogers, C.M.; Morris, G.E.; Gould, T.W.; Bail, R.; Toumpaniari, S.; Harrington, H.; Dixon, J.E.; Shakesheff, K.M.; Segal, J.; Rose, F.R. A novel technique for the production of electrospun scaffolds with tailored three-dimensional micro-patterns employing additive manufacturing. Biofabrication 2014, 6, 035003. [CrossRef] [PubMed]

42. Caplan, A.I.; Dennis, J.E. Mesenchymal stem cells as trophic mediators. J. Cell. Biochem. 2006, 98, 1076-1084. [CrossRef] [PubMed]

43. Phipps, M.C.; Clem, W.C.; Grunda, J.M.; Clines, G.A.; Bellis, S.L. Increasing the pore sizes of bone-mimetic electrospun scaffolds comprised of polycaprolactone, collagen I and hydroxyapatite to enhance cell infiltration. Biomaterials 2012, 33, 524-534. [CrossRef] [PubMed]

44. Ynsa, M.D.; Dang, Z.Y.; Manso-Silvan, M.; Song, J.; Azimi, S.; Wu, J.F.; Liang, H.D.; Torres-Costa, V.; Punzon-Quijorna, E.; Breese, M.B.H.; et al. Reprogramming hMSCs morphology with silicon/porous silicon geometric micro-patterns. Biomed. Microdevices 2014, 16, 229-236. [CrossRef] [PubMed]

45. Das, R.K.; Zouani, O.F. A review of the effects of the cell environment physicochemical nanoarchitecture on stem cell commitment. Biomaterials 2014, 35, 5278-5293. [CrossRef]

46. Trappmann, B.; Gautrot, J.E.; Connelly, J.T.; Strange, D.G.; Li, Y.; Oyen, M.L.; Cohen Stuart, M.A.; Boehm, H.; Li, B.; Vogel, V.; et al. Extracellular-matrix tethering regulates stem-cell fate. Nat. Mater. 2012, 11, 642-649. [CrossRef]

47. Ayala, R.; Zhang, C.; Yang, D.; Hwang, Y.; Aung, A.; Shroff, S.S.; Arce, F.T.; Lal, R.; Arya, G.; Varghese, S. Engineering the cell-material interface for controlling stem cell adhesion, migration, and differentiation. Biomaterials 2011, 32, 3700-3711. [CrossRef]

48. Tan, K.Y.; Lin, H.; Ramstedt, M.; Watt, F.M.; Huck, W.T.; Gautrot, J.E. Decoupling geometrical and chemical cues directing epidermal stem cell fate on polymer brush-based cell micro-patterns. Integr. Biol. 2013, 5, 899-910. [CrossRef]

49. Charest, J.L.; Eliason, M.T.; García, A.J.; King, W.P. Combined microscale mechanical topography and chemical patterns on polymer cell culture substrates. Biomaterials 2006, 27, 2487-2494. [CrossRef]

50. Flemming, R.G.; Murphy, C.J.; Abrams, G.A.; Goodman, S.L.; Nealey, P.F. Effects of synthetic micro- and nano-structured surfaces on cell behavior. Biomaterials 1999, 20, 573-588. [CrossRef]

51. Green, A.M.; Jansen, J.A.; Waerden, J.P.C.M.v.d.; Recum, A.F.V. Fibroblast response to microtextured silicone surfaces: Texture orientation into or out of the surface. J. Biomed. Mater. Res. Part A 1994, 28, 647-653. [CrossRef] [PubMed]

52. Feng, Y.; Ma, X.; Chang, L.; Zhu, S.; Guan, S. Characterization and cytocompatibility of polydopamine on MAO-HA coating supported on Mg-Zn-Ca alloy. Surf. Interface Anal. 2017, 49, 1115-1123. [CrossRef]

53. Li, C.; Li, J.A.; Chang, J.W.; Jin, S.B.; Wu, D.; Yan, H.H.; Wang, X.F.; Guan, S.K. Mg-Zn-Y-Nd coated with citric acid and dopamine by layer-by-layer self-assembly to improve surface biocompatibility. Sci. China Technol. Sci. 2018, 1-10. [CrossRef]

54. Liu, Y.; Liu, J.; Sohn, S.; Li, Y.; Cha, J.J.; Schroers, J. Metallic glass nanostructures of tunable shape and composition. Nat. Commun. 2015, 6, 7043. [CrossRef]

55. Kumar, G.; Tang, H.X.; Schroers, J. Nanomoulding with amorphous metals. Nature 2009, 457, $868-872$. [CrossRef]

56. Hasan, M.; Schroers, J.; Kumar, G. Functionalization of Metallic Glasses through Hierarchical Patterning. Nano Lett. 2015, 15, 963. [CrossRef] [PubMed]

57. Wang, J.; Zhu, S.; Wang, L.; Guan, S.; Li, R.; Zhang, T. Hard rhenium-boron-cobalt amorphous alloys with a wide supercooled liquid region. Mater. Sci. Eng. A 2015, 645, 122-125. [CrossRef]

58. Wang, J.; Di, Y.; Fang, Z.; Guan, S.; Zhang, T. Thermal stability, crystallization and soft magnetic properties of Fe-P-C-based glassy alloys. J. Non-Cryst. Solids 2016, 454, 39-45. [CrossRef]

59. Liu, L.; Hasan, M.; Kumar, G. Metallic glass nanostructures: Fabrication, properties, and applications. Nanoscale 2014, 6, 2027-2036. [CrossRef] [PubMed]

60. Wang, J.; Loye, A.M.; Ketkaew, J.; Schroers, J.; Kyriakides, T.R. Hierarchical Micro- and Nanopatterning of Metallic Glass to Engineer Cellular Responses. ACS Appl. Biol. Mater. 2018, 1, 51-58. [CrossRef]

61. Roy, P.; Berger, S.; Schmuki, P. $\mathrm{TiO}_{2}$ nanotubes: Synthesis and applications. Angew. Chem. Int. Ed. 2011, 50, 2904-2939. [CrossRef]

62. Gong, D.; Grimes, C.A.; Varghese, O.K.; Hu, W.; Singh, R.S.; Chen, Z.; Dickey, E.C. Titanium oxide nanotube arrays prepared by anodic oxidation. J. Mater. Res. 2011, 16, 3331-3334. [CrossRef] 
63. Peng, L.; Eltgroth, M.L.; Latempa, T.J.; Grimes, C.A.; Desai, T.A. The effect of TiO nanotubes on endothelial function and smooth muscle proliferation. Biomaterials 2009, 30, 1268-1272. [CrossRef] [PubMed]

64. Park, J.; Bauer, S.; Schmuki, P.; Von, d.M.K. Narrow window in nanoscale dependent activation of endothelial cell growth and differentiation on $\mathrm{TiO}_{2}$ nanotube surfaces. Nano Lett. 2009, 9, 3157-3164. [CrossRef] [PubMed]

65. Zhao, L.; Liu, L.; Wu, Z.; Zhang, Y.; Chu, P.K. Effects of micropitted/nanotubular titania topographies on bone mesenchymal stem cell osteogenic differentiation. Biomaterials 2012, 33, 2629. [CrossRef] [PubMed]

66. Li, X.; Liu, H.; Niu, X.; Yu, B.; Fan, Y.; Feng, Q.; Cui, F.Z.; Watari, F. The use of carbon nanotubes to induce osteogenic differentiation of human adipose-derived MSCs invitro and ectopic bone formation invivo. Biomaterials 2012, 33, 4818-4827. [CrossRef] [PubMed]

67. Popat, K.C.; Leoni, L.; Grimes, C.A.; Desai, T.A. Influence of engineered titania nanotubular surfaces on bone cells. Biomaterials 2007, 28, 3188-3197. [CrossRef]

68. Brammer, K.S.; Frandsen, C.J.; Jin, S. $\mathrm{TiO}_{2}$ nanotubes for bone regeneration. Trends Biotechnol. 2012, $30,315$. [CrossRef]

69. Gao, A.; Hang, R.; Huang, X.; Zhao, L.; Zhang, X.; Wang, L.; Tang, B.; Ma, S.; Chu, P.K. The effects of titania nanotubes with embedded silver oxide nanoparticles on bacteria and osteoblasts. Biomaterials 2014, 35, 4223-4235. [CrossRef] [PubMed]

70. Wang, T.; Liu, X.; Zhu, Y.; Cui, Z.D.; Yang, X.J.; Pan, H.; Yeung, K.W.K.; Wu, S. Metal Ion Coordination Polymer-Capped pH-Triggered Drug Release System on Titania Nanotubes for Enhancing Self-antibacterial Capability of Ti Implants. ACS Biomater. Sci. Eng. 2017, 3, 816-825. [CrossRef]

71. Zhang, W.B.; Shen, Y.H.; Pan, H.B.; Lin, K.L.; Liu, X.G.; Darvell, B.W.; Lu, W.W.; Chang, J.A.; Deng, L.F.; Wang, D.P.; et al. Effects of strontium in modified biomaterials. Acta Biomater. 2011, 7, 800-808. [CrossRef] [PubMed]

72. Querido, W.; Rossi, A.L.; Farina, M. The effects of strontium on bone mineral: A review on current knowledge and microanalytical approaches. Micron 2016, 80, 122-134. [CrossRef] [PubMed]

73. Chen, Y.; Gao, A.; Bai, L.; Wang, Y.; Wang, X.; Zhang, X.; Huang, X.; Hang, R.; Tang, B.; Chu, P.K. Antibacterial, osteogenic, and angiogenic activities of $\mathrm{SrTiO}_{3}$ nanotubes embedded with $\mathrm{Ag}_{2} \mathrm{O}$ nanoparticles. Mater. Sci. Eng. C 2017, 75, 1049-1058. [CrossRef] [PubMed]

74. Sima, F.; Socol, G.; Axente, E.; Mihailescu, I.N.; Zdrentu, L.; Petrescu, S.M.; Mayer, I. Biocompatible and bioactive coatings of $\mathrm{Mn}^{2+}$-doped $\beta$-tricalcium phosphate synthesized by pulsed laser deposition. Appl. Surf. Sci. 2007, 254, 1155-1159. [CrossRef]

75. Huang, Y.; Wang, W.; Zhang, X.; Liu, X.; Xu, Z.; Han, S.; Su, Z.; Liu, H.; Gao, Y.; Yang, H. A prospective material for orthopedic applications: Ti substrates coated with a composite coating of a titania-nanotubes layer and a silver-manganese-doped hydroxyapatite layer. Ceram. Int. 2018, 44, 5528-5542. [CrossRef]

76. Rho, J.Y.; Kuhn-Spearing, L.; Zioupos, P. Mechanical properties and the hierarchical structure of bone. Med. Eng. Phys. 1998, 20, 92. [CrossRef]

77. Zhao, L.; Mei, S.; Chu, P.K.; Zhang, Y.; Wu, Z. The influence of hierarchical hybrid micro/nano-textured titanium surface with titania nanotubes on osteoblast functions. Biomaterials 2010, 31, 5072-5082. [CrossRef]

78. Lee, H.; Dellatore, S.M.; Miller, W.M.; Messersmith, P.B. Mussel-inspired surface chemistry for multifunctional coatings. Science 2007, 318, 426-430. [CrossRef]

79. Jia, Z.; Xiu, P.; Li, M.; Xu, X.; Shi, Y.; Cheng, Y.; Wei, S.; Zheng, Y.; Xi, T.; Cai, H. Bioinspired anchoring AgNPs onto micro-nanoporous $\mathrm{TiO}_{2}$ orthopedic coatings: Trap-killing of bacteria, surface-regulated osteoblast functions and host responses. Biomaterials 2016, 75, 203-222. [CrossRef]

80. Hong, X.; Xue, S.; Hui, M.; Lv, Y.; Zhang, L.; Mao, Z. The preparation and antibacterial effects of dopa-cotton/AgNPs. Appl. Surf. Sci. 2011, 257, 6799-6803. [CrossRef]

81. Wu, C.; Han, P.; Liu, X.; Xu, M.; Tian, T.; Chang, J.; Xiao, Y. Mussel-inspired bioceramics with self-assembled $\mathrm{Ca}-\mathrm{P} /$ polydopamine composite nanolayer: Preparation, formation mechanism, improved cellular bioactivity and osteogenic differentiation of bone marrow stromal cells. Acta Biomater. 2014, 10, 428-438. [CrossRef] [PubMed]

82. Saidin, S.; Chevallier, P.; Abdul Kadir, M.R.; Hermawan, H.; Mantovani, D. Polydopamine as an intermediate layer for silver and hydroxyapatite immobilisation on metallic biomaterials surface. Mater. Sci. Eng. C 2013, 33, 4715-4724. [CrossRef] 
83. Ding, X.; Zhang, Y.; Ling, J.; Lin, C. Rapid mussel-inspired synthesis of PDA-Zn-Ag nanofilms on $\mathrm{TiO}_{2}$ nanotubes for optimizing the antibacterial activity and biocompatibility by doping polydopamine with zinc at a higher temperature. Colloids Surf. B 2018, 171, 101-109. [CrossRef] [PubMed]

84. Harrison, B.S.; Atala, A. Carbon nanotube applications for tissue engineering. Biomaterials 2007, 28, 344-353. [CrossRef] [PubMed]

85. Zaborowska, M.; Bodin, A.; Bäckdahl, H.; Popp, J.; Goldstein, A.; Gatenholm, P. Microporous bacterial cellulose as a potential scaffold for bone regeneration. Acta Biomater. 2010, 6, 2540-2547. [CrossRef]

86. Svensson, A.; Nicklasson, E.; Harrah, T.; Panilaitis, B.; Kaplan, D.L.; Brittberg, M.; Gatenholm, P. Bacterial cellulose as a potential scaffold for tissue engineering of cartilage. Biomaterials 2005, 26, 419-431. [CrossRef] [PubMed]

87. Lin, S.P.; Calvar, I.L.; Catchmark, J.M.; Liu, J.R.; Demirci, A.; Cheng, K.C. Biosynthesis, production and applications of bacterial cellulose. Cellulose 2013, 20, 2191-2219. [CrossRef]

88. Mohite, B.V.; Patil, S.V. A novel biomaterial: Bacterial cellulose and its new era applications. Biotechnol. Appl. Biochem. 2014, 61, 101-110. [CrossRef]

89. Xavier Acasigua, G.A.; de Olyveira, G.M.; Manzine Costa, L.M.; Braghirolli, D.I.; Medeiros Fossati, A.C.; Guastaldi, A.C.; Pranke, P.; Daltro, G.C.; Basmaji, P. Novel chemically modified bacterial cellulose nanocomposite as potential biomaterial for stem cell therapy applications. Curr. Stem Cell Res. Ther. 2014, 9, 117-123. [CrossRef]

90. Gutierrez-Hernandez, J.M.; Escobar-Garcia, D.M.; Escalante, A.; Flores, H.; Gonzalez, F.J.; Gatenholm, P.; Toriz, G. In vitro evaluation of osteoblastic cells on bacterial cellulose modified with multi-walled carbon nanotubes as scaffold for bone regeneration. Mater. Sci. Eng. C 2017, 75, 445-453. [CrossRef]

91. Campoccia, D.; Montanaro, L.; Arciola, C.R. A review of the biomaterials technologies for infection-resistant surfaces. Biomaterials 2013, 34, 8533. [CrossRef] [PubMed]

92. Campoccia, D.; Montanaro, L.; Arciola, C.R. A review of the clinical implications of anti-infective biomaterials and infection-resistant surfaces. Biomaterials 2013, 34, 8018. [CrossRef]

93. Arciola, C.R.; Campoccia, D.; Speziale, P.; Montanaro, L.; Costerton, J.W. Biofilm formation in Staphylococcus implant infections. A review of molecular mechanisms and implications for biofilm-resistant materials. Biomaterials 2012, 33, 5967. [CrossRef] [PubMed]

94. Cloutier, M.; Mantovani, D.; Rosei, F. Antibacterial Coatings: Challenges, Perspectives, and Opportunities. Trends Biotechnol. 2015, 33, 637-652. [CrossRef] [PubMed]

95. Hasan, J.; Crawford, R.J.; Ivanova, E.P. Antibacterial surfaces: The quest for a new generation of biomaterials. Trends Biotechnol. 2013, 31, 295. [CrossRef] [PubMed]

96. Yu, Q.; Wu, Z.; Chen, H. Dual-function antibacterial surfaces for biomedical applications. Acta Biomater. 2015, 16, 1. [CrossRef]

97. Sondi, I.; Salopek-Sondi, B. Silver nanoparticles as antimicrobial agent: A case study on E. coli as a model for Gram-negative bacteria. J. Colloid Interface Sci. 2004, 275, 177-182. [CrossRef]

98. Wei, L.; Lu, J.; Xu, H.; Patel, A.; Chen, Z.S.; Chen, G. Silver nanoparticles: Synthesis, properties, and therapeutic applications. Drug Discover. Today 2015, 20, 595-601. [CrossRef]

99. Durán, N.; Durán, M.; de Jesus, M.B.; Seabra, A.B.; Fávaro, W.J.; Nakazato, G. Silver Nanoparticles: A New View on Mechanistic Aspects on Antimicrobial Activity. Nanomed. Nanotechnol. 2016, 12, 789-799. [CrossRef]

100. Ciobanu, C.S.; Iconaru, S.L.; Coustumer, P.L.; Constantin, L.V.; Predoi, D. Antibacterial activity of silver-doped hydroxyapatite nanoparticles against gram-positive and gram-negative bacteria. Nanoscale Res. Lett. 2012, 7, 324. [CrossRef]

101. Li, Z.; Lee, D.; Sheng, X.; Cohen, R.E.; Rubner, M.F. Two-level antibacterial coating with both release-killing and contact-killing capabilities. Langmuir 2006, 22, 9820-9823. [CrossRef] [PubMed]

102. Asharani, P.V.; Low, K.M.G.; Hande, M.P.; Valiyaveettil, S. Cytotoxicity and genotoxicity of silver nanoparticles in human cells. ACS Nano 2009, 3, 279-290. [CrossRef] [PubMed]

103. Cao, H.; Qiao, Y.; Liu, X.; Lu, T.; Cui, T.; Meng, F.; Chu, P.K. Electron storage mediated dark antibacterial action of bound silver nanoparticles: Smaller is not always better. Acta Biomater. 2013, 9, 5100. [CrossRef] [PubMed]

104. Wang, G.; Jin, W.; Qasim, A.M.; Gao, A.; Peng, X.; Li, W.; Feng, H.; Chu, P.K. Antibacterial effects of titanium embedded with silver nanoparticles based on electron-transfer-induced reactive oxygen species. Biomaterials 2017, 124, 25-34. [CrossRef] [PubMed] 
105. Qin, H.; Cao, H.; Zhao, Y.; Zhu, C.; Cheng, T.; Wang, Q.; Peng, X.; Cheng, M.; Wang, J.; Jin, G.; et al. In vitro and in vivo anti-biofilm effects of silver nanoparticles immobilized on titanium. Biomaterials 2014, 35, 9114-9125. [CrossRef]

106. Taglietti, A.; Arciola, C.R.; D’Agostino, A.; Dacarro, G.; Montanaro, L.; Campoccia, D.; Cucca, L.; Vercellino, M.; Poggi, A.; Pallavicini, P.; et al. Antibiofilm activity of a monolayer of silver nanoparticles anchored to an amino-silanized glass surface. Biomaterials 2014, 35, 1779-1788. [CrossRef]

107. Marta, R.; Monteiro, F.J.; Ferraz, M.P. Infection of orthopedic implants with emphasis on bacterial adhesion process and techniques used in studying bacterial-material interactions. Biomatter 2012, 2, 176-194. [CrossRef]

108. Costerton, J.W.; Stewart, P.S.; Greenberg, E.P. Bacterial biofilms: A common cause of persistent infections. Science 1999, 284, 1318-1322. [CrossRef]

109. Hu, H.; Zhang, W.; Qiao, Y.; Jiang, X.; Liu, X.; Ding, C. Antibacterial activity and increased bone marrow stem cell functions of $\mathrm{Zn}$-incorporated $\mathrm{TiO}_{2}$ coatings on titanium. Acta Biomater. 2012, 8, 904-915. [CrossRef]

110. Jin, G.; Qin, H.; Cao, H.; Qian, S.; Zhao, Y.; Peng, X.; Zhang, X.; Liu, X.; Chu, P.K. Synergistic effects of dual $\mathrm{Zn} / \mathrm{Ag}$ ion implantation in osteogenic activity and antibacterial ability of titanium. Biomaterials 2014, 35, 7699-7713. [CrossRef]

111. Mohandas, A.; Krishnan, A.G.; Biswas, R.; Menon, D.; Nair, M.B. Antibacterial and cytocompatible nanotextured Ti surface incorporating silver via single step hydrothermal processing. Mater. Sci. Eng. C 2017, 75, 115-124. [CrossRef] [PubMed]

112. Tsuji, K.; Bandyopadhyay, A.; Harfe, B.D.; Cox, K.; Kakar, S.; Gerstenfeld, L.; Einhorn, T.; Tabin, C.J.; Rosen, V. BMP2 activity, although dispensable for bone formation, is required for the initiation of fracture healing. Nat. Genet. 2006, 38, 1424-1429. [CrossRef] [PubMed]

113. Rosen, V. BMP2 signaling in bone development and repair. Cytokine Growth Factor Rev. 2009, $20,475-480$. [CrossRef] [PubMed]

114. Li, Z.; Hassan, M.Q.; Volinia, S.; Wijnen, A.J.V.; Stein, J.L.; Croce, C.M.; Lian, J.B.; Stein, G.S. A microRNA signature for a BMP2-induced osteoblast lineage commitment program. Proc. Natl. Acad. Sci. USA 2008, 105, 13906-13911. [CrossRef] [PubMed]

115. Xie, C.M.; Lu, X.; Wang, K.F.; Meng, F.Z.; Jiang, O.; Zhang, H.P.; Zhi, W.; Fang, L.M. Silver nanoparticles and growth factors incorporated hydroxyapatite coatings on metallic implant surfaces for enhancement of osteoinductivity and antibacterial properties. ACS Appl. Mater. Interfaces 2014, 6, 8580-8589. [CrossRef] 